the specialized literature. It was determined that under a way dangerous for life and health of a person we shall understand such a way of committing the said crime which creates real danger of death of a victim or causing him/her severe, medium severity or light bodily injury that causes short time health issues or moderate loss of working capabilities. Whether such injuries are caused needs additional qualification according to the articles that provide for responsibility for corresponding crimes against life and health of a person, or is covered by the notion of «grave consequences» and is qualified by the part 3 art. 146 of the Criminal Code of Ukraine.

The practice of the criminal law assessment of unlawful deprivation of liberty as such has been also very various during a long period of time. The courts virtually never indicate that by qualifying the said crime in this way they take into consideration not only the time during which a person was deprived of liberty but also consider the way and place where a person was held, other specific circumstance of a case, state of health, age etc.

It has been determined that as grave consequences caused by unlawful deprivation of liberty or abduction, the courts mostly take into account causing the death of a victim, willfully or carelessly.

It has been established that a part of analyzed mistakes is connected to deficiencies (mostly terminological) of the current edition of art. 146 of the Criminal Code of Ukraine, however, most of them are caused by the insufficient professional level of investigators, prosecutors, and judges.

Key words: crimes against the will, honor and dignity of a person; unlawful deprivation of liberty or kidnapping; self-serving motives; way dangerous to the life or health of the victim; causing physical suffering; grave consequences; criminal law qualification.

DOI: 10.36695/2219-5521.3.2019.37

УДК $343.3 / .7 ; 343.9$

А.В. ЛАНДІНА, О.М. ЛИСЕНКО

Анна Валентинівна Ландіна, кандидат юридичних наук, старший науковий співробітник Інституту держави і права ім. В.М. Корецького НАН України*

ORCID: 0000-0002-3808-7573

Олександр Миколайович Лисенко, кандидат політичних наук, завідувач кафредри Східноєвропейського університету економіки і менеджмен$m y^{* *}$

ORCID: 0000-0001-7817-4199

\title{
КРИМІНАЛЬНО-ПРАВОВІ ЗАХОДИ ЗАПОБІГАННЯ АЛКОГОЛІЗМУ: ПОРІВНЯЛЬНО-ПРАВОВИЙ АСПЕКТ
}

Постановка проблеми. Алкоголізм - це хвороба, яка виходить за межі окремої особи і набуває характеру загальнодержавного і навіть міжнародного характеру. Це негативне соціальне явище є небезпечним саме по собі. Але особливою небезпечністю характеризують інші антисоціальні явища, які відбувають в суспільстві під впливом алкоголю. Зокрема, таким проявом є вчинення злочинів у стані алкогольного сп'яніння, порушення громадського порядку, прояви неповаги як до окремих громадян, так і до суспільства в цілому, потяг до вживання всі більшої кількості алкоголю тощо.

Надмірне вживання алкоголю у суспільстві має ряд негативних наслідків. Зокрема, чиниться негативний вплив на економіку, оскільки алкоголізм негативно впливає на якість праці осіб, схильних до його вживання; на загальний стан здоров'я населення; на моральний і культурний рівень розвитку населення. Тому і вироблення засобів протидії цьому явищу лежить у площині багатьох галузей та напрямів державної політики.

Протидія поширення алкоголізму серед населення є однією з основних задач, яка стоїть перед урядовими і неурядовими організаціями, оскільки руйнівний вплив розповсюдження алкоголізму на загальний рівень культурного, соціального, політичного та економічного життя важко переоцінити. Вона включає широке коло заходів профілактики і запобігання алкоголізму, що реалізуються на практиці у різних сферах державної політики та діяльності громадських та державних організацій та установ, серед яких не останнє місце займають кримінально-правові заходи, що застосовуються до осіб, які вчинили злочини у стані алкогольного сп'яніння.

Аналіз останніх досліджень і публікацій. Проблеми протидії розповсюдження алкоголізму були предметом дослідження багатьох вчених. Зокрема, ці питання у різних наукових сферах вивчали такі вчені, як В.Д. Воднік, Ю.В. Дрозд, О.І. Минко, Н.Г. Радченко, С.М. Руденко та інші. Що стосується застосування у цій

() А.В. Ландіна, О.М. Лисенко, 2019

* Anna Landina, Ph.D. in Law, senior researcher of V.M. Koretsky Institute of State and Law of NAS of Ukraine

** Oleksandr Lysenko, Ph.D. in Politology, head of the Department of the Eastern European University Economics and management

Часопис Київського університету права • 2019/3 
сфері саме кримінально-правових заходів, то даному аспекту були присвячені праці В.С. Батиргареєвої, В.М. Бурдіна, О.О. Кашкарова, В.В. Леня та інших. Натомість саме порівняльно-правовий аспект кримінально-правової протидії алкоголізму серед населення $є$ малодослідженим і вимагає більш глибокого опрацювання. Саме проведення компаративістського дослідження норм кримінального законодавства зарубіжних країн забезпечить можливість удосконалення норм вітчизняного кримінального законодавства і підвищить рівень протидії розповсюдження алкоголізму.

Формулювання мети статті. Враховуючи викладене вище, метою даного дослідження буде удосконалення вітчизняних кримінально-правових заходів протидії алкоголізму. Згідно з поставленою метою завданнями статті будуть виявлення кримінально-правових заходів протидії алкоголізму у зарубіжному кримінальному законодавстві і зіставлення їх із відповідними заходами, передбаченими у КК України.

Виклад основного матеріалу. Притягнення до кримінальної відповідальності є найбільш репресивною, караючої формою державного засудження осіб, які вчинили кримінально каране діяння. Однак однією з головних функцій кримінального покарання виступає завдання перевиховання засуджених у дусі чесного ставлення до праці, суворого і точного виконання законів, поваги до правил співжиття, а також попередження злочинності в цілому, що має пряме відношення до злочинів, вчинених у стані сп'яніння. Саме тому кримінальне законодавство, окрім каральних, містить і інші заходи кримінально-правового впливу.

Так, КК України містить окремий Розділ XIV «Примусові заходи медичного характеру та примусове лікування», у якому передбачені підстави застосування щодо особи примусового лікування, зокрема, «примусове лікування може бути застосоване судом, незалежно від призначення покарання, до осіб, які вчинили злочини та мають хворобу, що становить небезпеку для здоров'я інших осіб. I хоча очевидної суспільної небезпечності в алкоголізмі наче б то і немає, але враховуючи вказане вище, а також те, що алкоголізм може передаватися генетично ${ }^{1}$, то ми вважаємо, що алкоголізм як хвороба $є$ небезпечним для суспільства. Про це свідчить і положення п. 13 ст. 67 КК України, яка визначає, що вчинення злочину особою, яка перебуває у стані алкогольного сп'яніння, визнається обставиною, яка обтяжує покарання.

Також КК України містить і норми, що регламентують заходи протидії алкоголізму. Це, зокрема, п. 5 ч. 2 ст. 76, в якій зазначається, що на особу, яка звільнена від відбування покарання з випробуванням, судом може бути покладений обов’язок «пройти курс лікування від алкоголізму...». I цей захід $\epsilon$, на наш погляд, не меш ефективним, ніж примусове лікування.

Стосовно зарубіжного кримінального законодавства, то чинні кримінальні кодекси преважної більшості держав континентальної Свропи, держав пострадянського простору містять кримінально-правові засоби боротьби з алкоголізмом. Положення про такі засоби містяться, зокрема, щодо призначення покарань - у нормах кримінальних кодексів Республіки Казахстан, Республіки Туркменістан, Киргизької Республіки, Азербайджанської Республіки, Республіки Білорусь, Грузії, Республіки Молдова, Латвійської Республіки, Республіки Вірменія, Албанії, Швейцарії, Норвегії, Швеції, Республіки Польща, Республіки Таджикистан, Литовської Республіки, Франції; заходів безпеки - КК Угорщини, КК Австрії; про звільнення від покарання в кримінальних кодексах Російської Федерації, Республіки Білорусь, Грузії, Республіки Вірменія, Республіки Таджикистан, Киргизької Республіки, Республіки Казахстан, Литовської Республіки, Республіки Туркменістан, КК Швейцарії, КК Естонії.

Кримінальне законодавство деяких країн містить норму, у якій зазначається, що суд може зобов'язати особу, що підлягає умовно-достроковому звільненню від покарання, пройти відповідний курс лікування від алкоголізму у спеціальному закладі (ч. 5 ст. 90, ч. 4 ст. 77 КК Республіки Білорусь) $)^{2}$. Дещо подібна норма міститься і у КК Данії (ст. 57), яка містить перелік цілого ряду обов'язків, які суб'єкт злочину повинен виконувати (чи дотримуватися) протягом періоду пробації (усього або лише певної його частини), зокрема: утримання від зловживання алкогольними напоями; обов'язкове проходження курсу лікування від алкоголізму, у тому числі у спеціалізованому медичному закладі або спеціалізованій лікарні³.

Окрім спеціальних заходів, спрямованих конкретно на лікування алкоголізму у осіб, що вчинили злочини у стані алкогольного сп'яніння, зарубіжне кримінальне законодавство містить і інші положення, які супроводжують покарання (чи інші кримінально-правові заходи) та спрямовані на протидію вживання алкоголю суб'єктами злочинів, які схильні до цього. До таких можна віднести наступні: суб'єкт злочину, який відбуває покарання, зобов'язаний повністю утримуватися від вживання алкогольних напоїв (КК Республіки Польща, ст. 75 КК Естонської Республіки, ст. 73 КК Республіки Сербія, п. «с» ч. 3 § 53 КК Норвегіï)4; особі, винуватій у вчиненні злочину, протягом існування кримінально-правових відносин заборонено вживати алкогольні напої (п. 2 абз.2 § 51 КК Австрії, ч. 2 ст. 41 КК Швейцарії)5; особі, щодо якої застосована пробація, заборонено відвідувати і здійснювати покупки в магазинах, що продають будь-які алкогольні напої (КК Албанії) ${ }^{6}$.

Крім того, у зарубіжному кримінальному законодавстві вказуються й інші заходи профілактики і протидії алкоголізму, які стосуються злочинців, схильних до вживання алкоголю опосередковано, завдяки впливу інших осіб. Наприклад, ст. 70 КК Угорщини містить положення про примусову турботу про алкоголіків 3 боку близьких, рідних чи інших осіб7; можливе навіть відстрочення покарання за умови, що суб'єкт злочину пройде курс антиалкогольної пропаганди (п. «е» ч. 3 § 3 КК Норвегії). Також передбачаються й інші заходи запобігання подальшому вживанню алкогольних напоїв особами, які вчинили злочин: встановлення опіки над особами, схильними до вживання алкоголю чи хворими на алкоголізм (ст. 103 «Застосування примусових заходів медичного характеру до алкоголіків і наркоманів» КК Республіки Молдова) ${ }^{8}$; встановлення 
обов'язкового контролю, турботи чи трітменту щодо особи, схильної до вживання алкоголю, щоб припинити інтоксикацію організму (ч. 3 ст. 103 КК Румунії) ; щодо осіб, які вчинили злочин і мають схильність до вживання алкоголю, регламентується обов'язковий медичний трітмент (ч. 3 ст. 61 КК Федерації Боснії та Герцеговини) ${ }^{10}$. Такі ж методи застосовуються, як правило, і при лікуванні алкоголізму (хронічного алкоголізму) у вказаних країнах.

Передбачається також і примусове лікування від алкогольної залежності у тих випадках, якщо злочин вчинювався під впливом залежності особи від алкогольних напоїв, а також є реальна небезпека того, що особа і далі буде вчинювати злочинні діяння (ст. 66 КК Республіки Словенія) ${ }^{11}$. Аналогічну за своєю сутністю норму містить і кримінальне законодавство Республіки Хорватія (ст. 68)12. У ст. 75 КК Угорщини, зазначається, що примусова турбота про алкоголіків може призначатися у тому випадку, якщо вчинення злочину пов'язане саме із алкоголізмом чи надмірним вживанням алкоголю винною особою. Деякі зарубіжні кримінальні кодекси передбачають навіть направлення особи, яка має залежність до надмірного вживання алкогольних напоїв, а також схильність до подальшого вчинення злочинів, у спеціальну установу, де ця особа буде перебувати в ізоляції (§ 64 КК ФРН та § 22КК Австрії)13.

Також у багатьох кодексах вказується, що у випадку, якщо вчинення злочину (злочинів) напряму залежить від схильності особи до вживання алкоголю та алкоголізму, щодо особи судом повинно застосовуватися лікування від вказаної соціально небезпечної хвороби. У випадку застосування такого заходу відбувається і застосування різних кримінально-правових заходів, зокрема, умовне засудження (ст. 70.5 КК Азербайджанської Республіки $\left.{ }^{14}\right)$; засудження з відстрочкою покарання засудження з умовним незастосуванням покарань (ч. 4 ст. 77 та ч. 5 ст. 78 КК Республіки Білорусь); умовне незастосування покарання (ч. 5 ст. 70 КК Республіки Вірменія) ${ }^{15}$; умовне засудження (п. «с» ст. 90 КК Республіки Молдова); як додатковий вид покарання (ст. 92 КК Республіки Болгарія) ${ }^{16}$.

Також у ст. 65 КК Латвійської Республіки зазначено, що особа, яка вчинила злочин під впливом надмірного вживання алкогольних напоїв і була засуджена судом до відбування покарання, може бути піддана лікуванню від алкогольної залежності, але лише за умови ії згоди ${ }^{17}$. Майже аналогічні заходи передбачені і нормами інших зарубіжних кримінальних кодексів (ст. 83 та ст. 84 КК Республіки Сербія та ст. 71 та ст. 72 КК Республіки Чорногорія) ${ }^{18}$. Також обов'язкова згода на застосування щодо засудженої особи обов'язкового курсу лікування від алкогольної залежності передбачена і нормами кримінального законодавства інших держав (Республіки Польща, Латвійської Республіки, Литовської республіки, Естонської Республіки, Австрії тощо).

Така позиція законодавця формально є правильною, враховуючи положення Конституції України, а також Основних законів інших країн. Так, зокрема, ст. 2 ФРН передбачає наступне: «(1) Кожна людина має право на розвиток своєї особистості, оскільки вона не порушує прав інших і не посягає на конституційний правопорядок або моральний закон; (2) Кожен має право на життя і на особисту недоторканність. Свобода особи непорушна» 19 . Аналогічне положення міститься у ст. 29 Основного Закону України: «Кожна людина має право на свободу та особисту недоторканність».

Зазначається, що згода особи, засудженої за вчинення злочину, щодо застосування до неї заходів лікувального характеру, має основне значення власне для результативності самого цього лікування ${ }^{20}$. Але тут виникають деякі складнощі: особа, яка хворіє на алкоголізм, не завжди повною мірою усвідомлює свої вчинки та/або може керувати ними внаслідок інтоксикації організму. У такому випадку дана особа не може адекватно оцінити ситуацію та важливість заходів, які повинні бути застосовані. Тому беззаперечне застосування примусового лікування особи, залежної від алкоголю, $є$ неефективним. Отже, при застосуванні таких заходів потрібно зважати і на загальну ураженість алкоголізмом організму засудженої особи, хворої на алкоголізм.

Таким чином, аналіз зарубіжного кримінального законодавства продемонстрував, що протидія та запобігання розповсюдження алкоголізму і вчиненню злочинів під впливом вживання алкогольних напоїв $є$ актуальним питанням, якому присвячено окремі норми. Такі норми містить і КК України (що вказувалося на початку даної статті), але, на нашу думку, врегулювання даного питання вимагає певного удосконалення. Зокрема, видається слушною позиція зарубіжних законодавці, які передбачають встановлення заборони вживання алкогольних напоїв протягом терміну відбування покарання, а також положення щодо обов'язкового встановлення опіки над алкогольно-залежними особами і особами, хворими на алкоголізм.

Висновки. Враховуючи вказане вище, потрібно зазначити, що низка норм зарубіжного кримінального законодавства, які містять заходи запобігання розповсюдженню алкоголізму серед населення, а також профілактики цього явища у осіб, які вчинили злочини у стані алкогольного сп'яніння, є досить ефективними. Тому пропонуємо включити відповідні положення і у норми чинного КК України. Зокрема, варто доповнити Розділ XIV «Примусові заходи медичного характеру та примусове лікування» нормами, які передбачатимуть наступні заходи:

1. «Особа, яка вчинила злочин внаслідок вживання алкогольних напоїв, зобов'язана повністю утримуватися від вживання алкогольних напоїв».

2. «Над особами, що вчинили злочини під впливом алкоголю, які $є$ схильними до вживання алкоголю чи хворими на алкоголізм, обов'язково встановлюється опіка та контроль з боку рідних, близьких або інших осіб».

Вказані заходи сприятимуть підвищенню ефективності протидії вчиненню злочинів під впливом вживання алкоголю. 

C. 327.

${ }^{1}$ Кримінальне право України. Загальна частина: підручник / за ред. М.І. Мельника, В.А. Клименка. Київ: Атіка, 2008.

2 Уголовный кодекс Республики Беларусь : принят Палатой Представителей 2 июня 1999 г. ; одобрен Советом Республики 24 июня 1999 г. Санкт-Петербург : Юридический центр Пресс, 2001. 474 с.

3 Уголовный кодекс Дании / науч. ред. и предисл. С.С. Беляева ; пер. с датского и англ. С.С. Беляева, А.Н. Рычевой. Санкт-Петербург : Юридический центр Пресс, 2001. 230 с.

4 Уголовный кодекс Республики Польша / науч. ред. А.И. Лукашов, Н.Ф. Кузнецова ; вступ. ст. А.И. Лукашова, Э.А. Саркисовой ; пер. с польского Д.А. Барилович. Санкт-Петербург : Юридический центр Пресс, 2001. 234 с.; Уголовный кодекс Эстонской Республики / науч. ред. и пер. с эстонского В.В. Запевалова ; вступ. ст. Н.И. Мацнева. Санкт-Петербург : Юридический центр Пресс, 2001. 262 с.; Уголовный кодекс Республики Сербия / науч. редакт. и предисл. Ю.А. Кашубы ; пер. с англ. С. Карибова. Санкт-Петербург : Юридический центр Пресс, 2009. 268 с.; Уголовное законодательство Норвегии / науч. ред. и вступ. ст. Ю.В. Голика ; пер. с норвежского А.В. Жмени. Санкт-Петербург : Юридический центр Пресс, 2003. 375 с.

5 Уголовный кодекс Австрии / пер. с нем. А.В. Серебренниковой. Москва : ИКД «Зерцало-М», 2001. 144 с.; Уголовный кодекс Швейцарии / науч. ред., предисл. и пер. с нем. А.В. Серебренниковой. Санкт-Петербург : Юридический центр Пресс, 2002. $350 \mathrm{c}$.

${ }^{6}$ Criminal Code of the Republic of Albania : Law No. 7895, dated 27 January 1995). URL: http://www.wipo.int/edocs/lexdocs/ laws/en/al/al037en.pdf

7 Criminal Code of the Republic of Hungary : Act C of 2012. URL: http://www.refworld.org/pdfid/4c358dd22.pdf

8 Уголовный кодекс Республики Молдова / науч. ред., вступ. ст. А.И. Лукашова. Санкт-Петербург : Юридический центр Пресc, 2003. 408 c.

9 Criminal Code of the Republic of Romania : Lav \#286 of 17 July 2009. URL: http://www.legislationline.org/.../Romania Criminal_Code_am2012_EN.pdf.

10 Criminal Code of the Federation of Bosnia and Herzegovina. URL: http://www.ohr.int/?content : $\mathrm{d}=5230$

11 Kazenski zakonik Repyblike Slovenije. URL: http: //www.uradzodrogc.gov.si/zakoni/KAZENSKI_zakonik.pdf

12 Republike Hrvatske: Kazneni Zakon: No: 71-05-03/1-11-2, 21 listopada 2011. URL: http://www.wipo.int/wipolex/ru/text.jsp? file $\mathrm{id}=301780$

13 Уголовный кодекс Федеративной Республики Германии / науч. ред. и вступ. статья Д.А. Шестакова ; предисл. Г.-Г. Йешека ; пер. с нем. Н.С. Рачковой. Санкт-Петербург : Юридический центр Пресс, 2003. 524 с.

14 Уголовный кодекс Азербайджанской Республики / науч. ред., предисл. И.М. Рагимова ; пер. с азерб. Б.Э. Аббасова. Санкт-Петербург : Юридический центр Пресс, 2001. 325 с.

15 Уголовный кодекс Республики Армения / науч редакт. Е.Р. Азаряна, Н.И. Мацнева ; предисл. Е.Р. Азаряна ; пер. с армянского Р.З. Авакяна. Санкт-Петербург : Юридический центр Пресс, 2004. 450 с.

16 Уголовный кодекс Республики Болгария / науч. ред. А.И. Лукашова ; вступ. ст. Й.И. Айдарова ; пер. с болг. Д.В. Милушева, А.И. Лукашова. Санкт-Петербург : Юридический центр Пресс, 2001. 298 с.

17 Уголовный кодекс Латвийской Республики / науч. ред. и вступ. ст. А.И. Лукашова и Э.А. Саркисовой : пер. с латыш. А.И. Лукашова. Санкт-Петербург : Юридический центр Пресс, 2001. 313 с.

18 Zoran Stojanovic. Krivicno pravo. Opsti deo. - BeogradA Pravna knjiga, 2005. - 371 р.; Кривични законик Република Црне Горе // Службени листр ЦГ бр 70/2003 и 13/2004. Lege-Codul Penal. URL: http: www.declex.ro/coduri /

19 Основной закон Федеративной Республики Германии, 23 мая 1949 г. URL: https://www.1000dokumente.de/?c=doku ment de\&dokument $=0014$ gru\&object=translation $\& \mathrm{l}=\mathrm{ru}$

20 Яценко С.С. Кримінально-правові засоби боротьби з алкоголізмом та наркоманією: порівняльно-правовий підхід. URL: http://www.pravoznavec.com.ua/period/article/12947/\%D1

\section{References:}

Melnyk, M.I., Klymenko, V.A. (za red.). (2008). Kryminalne pravo Ukrainy. Zahalna chastyna. Kyiv: Atika

Uholovnyi kodeks Respublyky Belarus : pryniat Palatoi Predstavytelei 2 yiunia 1999 h. (2001). SPb. : Yzd-vo «Iurydycheskyi tsentr Press»

Beliaev, S.S. (nauch. red. y predysl.) (2001). Uholovnyi kodeks Danyy. SPb. : Yurydycheskyi tsentr Press

Lukashov, A.Y., Kuznetsova, N.F. (nauch. red.). (2001). Uholovnyi kodeks Respublyky Polsha. SPb. : Yzd-vo «Iurydycheskyi tsentr Press»

Zapevalova, V.V. (nauch. red. y per. s estonskoho). (2001). Uholovnyi kodeks Estonskoi Respublyky. SPb. : Yzd-vo «Iurydycheskyi tsentr Press»

Kashuba, Yu.A. (nauch. red. y predysl.). (2009). Uholovnyi kodeks Respublyky Serbyia. SPb. : Yurydycheskyi tsentr Press

Holyka, Yu.V. (nauch. red. y vstup. st.). (2003). Uholovnoe zakonodatelstvo Norvehyy. SPb. : Yurydycheskyi tsentr Press.

Serebrennykova, A.V. (per. s nem.) (2001). Uholovnyi kodeks Avstryy. M. : YKD «Zertsalo-M», Press

Serebrennykova, A.V. (nauch. red., predysl. y per. s nem.). (2002). Uholovnyi kodeks Shveitsaryy. SPb. : Yurydycheskyi tsentr

Criminal Code of the Republic of Albania : Law No. 7895, dated 27 January 1995). URL: http://www.wipo.int/edocs/lexdocs/ laws/en/al/al037en.pdf.

Criminal Code of the Republic of Hungary : Act C of 2012. URL: http://www.refworld.org/pdfid/4c358dd22.pdf

Lukashov, A.Y. (nauch. red., vstup. st.). (2003). Uholovnyi kodeks Respublyky Moldova. SPb. : Iurydycheskyi tsentr Press

Criminal Code of the Republic of Romania : Lav \#286 of 17 July 2009. URL: http://www.legislationline.org/.../Romania_Cri minal Code am2012 EN.pdf.

Criminal Code of the Federation of Bosnia and Herzegovina. URL: http://www.ohr.int/?content :d=5230

Kazenski zakonik Repyblike Slovenije. URL: http: //www.uradzod rogc.gov.si / zakoni / KAZENSKI zakonik.pdf

Republike Hrvatske: Kazneni Zakon: No: 71-05-03/1-11-2, 21 listopada 2011. URL: http://www.wipo.int/wipolex/ru/text.jsp? file id $=301780$

Shestakov, D.A. (nauch. red. y vstup. statia). (2003). Uholovnyi kodeks Federatyvnoi Respublyky Hermanyy. SPb. : Yurydycheskyi tsentr Press

Rahymov, Y.M. (nauch. red., predysl.). (2001). Uholovnyi kodeks Azerbaidzhanskoi Respublyky. SPb. : Iurydycheskyi tsentr Press 
Azarian, E.R., Matsnev, N.Y. (nauch redakt.). (2004). Uholovnyikodeks Respublyky Armenyia. SPb. : Yurydycheskyi tsentr Press, 2004. $450 \mathrm{~s}$

Lukashov, A.Y. (nauch. red.). (2001). Uholovnyi kodeks Respublyky Bolharyia. SPb. : Yurydycheskyi tsentr Press

Lukashov, A.Y., Sarkysova, E.A. (nauch. red.). (2001). Uholovnyi kodeks Latvyiskoi Respublyky. SPb. : Yurydycheskyi tsentr Press, 2001. $313 \mathrm{~s}$

Zoran Stojanovic. (2005). Krivicno pravo. Opsti deo. BeogradA Pravna knjiga

Kryvychny zakonyk Republyka Tsrne Hore // Sluzhbeny lystr TsH br 70/2003 y 13/2004.

Lege-Codul Penal. URL: http: www.declex.ro/coduri /

Osnovnoi zakon Federatyvnoi Respublyky Hermanyy, 23 maia 1949 h. URL: https://www.1000dokumente.de/?c=dokument_ de\&dokument $=0014$ gru\&object=translation\&l=ru

Yatsenko, S.S. Kryminalno-pravovi zasoby borotby z alkoholizmom ta narkomaniieiu: porivnialno-pravovyi pidkhid. URL: http://www.pravoznavec.com.ua/period/article/12947/\%D1

\section{Резюме}

Ландіна А.В., Лисенко О.М. Кримінально-правові заходи запобігання алкоголізму: порівняльно-правовий аспект.

У статті здійснено порівняльний аналіз норм зарубіжного кримінального законодавства, що передбачають заходи по запобіганню алкоголізму у осіб, які вчинили злочин у стані алкогольного сп'яніння, із відповідними нормами КК України. Зроблено висновок щодо необхідності доповнення КК України конкретними нормами, що підвищать ефективність запобігання алкоголізму серед суб'єктів злочинів.

Ключові слова: кримінально-правові заходи запобігання алкоголізму, суб'єкт злочину, стан сп'яніння, зарубіжне кримінальне законодавство.

\section{Резюме} аспккт.

Ландина А.В., Лысенко А.Н. Уголовно-правовые меры предотвращения алкоголизма: сравнительно-правовой

В статье осуществлен сравнительный анализ норм зарубежного уголовного законодательства, предусматривающих меры по предотвращению алкоголизма у лиц, которые совершили преступление в состоянии алкогольного опьянения, с соответствующими нормами УК Украины. Сделан вывод о необходимости дополнения УК Украины конкретными нормами, которые повысят эффективность предотвращения алкоголизма среди субъектов преступлений.

Ключевые слова: уголовно-правовые меры предотвращения алкоголизма, субъект преступления, состояние опьянения, зарубежное уголовное законодательство.

\section{Summary}

Anna Landina, Oleksandr Lysenko. Criminal and legal measures to prevent alcoholism: comparative legal aspect.

Combating the spread of alcoholism among the population is one of the main challenges faced by government and non-governmental organizations, since the devastating impact of the spread of alcoholism on the overall level of cultural, social, political and economic life is difficult to overestimate. It includes a wide range of measures to prevent alcoholism, are implemented in practice in different policy areas and activities of public and state organizations and institutions, among which not last place is occupied by criminal law measures that apply to persons who have committed crimes in an alcohol intoxication.

The problems of countering the spread of alcoholism have been the subject of research by many scientists. But it is the comparative legal aspect of the criminal legal counteraction to alcoholism among the population that is poorly researched and requires more in-depth study.

The purpose of this study will be to improve domestic criminal legal measures to combat alcoholism.

The criminal legislation, except punitive, contains also other measures of criminal-legal influence. The criminal code of Ukraine also contains norms regulating measures to counteract alcoholism. It, in particular, item 5 of part 2 of Art. 76 in which it is noted that the person released from serving of punishment with test, court can be assigned a duty "to pass a course of treatment from alcoholism...".

With regard to foreign criminal legislation, the existing criminal codes prevazhno in most countries of continental Europe, the post-Soviet States contain criminal legal means to combat alcoholism. Provisions for such funds, see, in particular, with respect to sentencing - in the norms of criminal codes of the Republic of Kazakhstan, Republic of Turkmenistan, the Kyrgyz Republic, the Republic of Azerbaijan, Belarus, Georgia, Republic of Moldova, the Republic of Latvia, the Republic of Armenia, Albania, Switzerland, Norway, Sweden, the Republic of Poland, the Republic of Tajikistan, the Republic of Lithuania, and France; security measures - Hungary UK, Austria UK,; exemption from punishment in the criminal codes of the Russian Federation, Belarus, Georgia, Republic of Armenia, the Republic of Tajikistan, the Kyrgyz Republic, Kazakhstan, Lithuania, Turkmenistan, UK Switzerland, UK Estonia.

The analysis of the foreign criminal legislation has shown that counteraction and prevention of alcoholism distribution and Commission of crimes under the influence of alcohol consumption, is an actual question to which separate norms are devoted. Such norms are contained in the criminal code (as indicated at the beginning of this article), but, in our opinion, the settlement of this issue requires some improvement. In particular, the position of foreign legislators, which provide for the establishment of a ban on the use of alcoholic beverages during the sentence, as well as provisions on the mandatory establishment of guardianship over alcohol-dependent persons and persons sick of alcoholism, seems convincing.

A number of norms of foreign criminal legislation containing measures to prevent the spread of alcoholism among the population, as well as the prevention of this phenomenon in persons who have committed crimes while intoxicated, are quite effective. Therefore, we propose to include the relevant provisions and norms of the current criminal code of Ukraine. legislation.

Key words: criminal and legal measures to prevent alcoholism, the subject of the crime, the state of intoxication, foreign criminal 